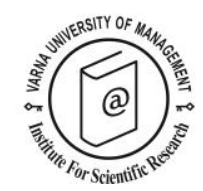

\title{
Evaluation of Potential Ecotourism Attractions for Sustainable Tourism Development in Anambra State, Nigeria
}

\author{
Chigozie Jude Odum ${ }^{1}$
}

Received: 02/03/2018

\footnotetext{
${ }^{1}$ Department of Archaeology and Tourism, University of Nigeria, Nsukka 410001 Enugu State, Nigeria. E-mail: jude.odum@unn.edu.ng
}

Supervisors: Associate Professor Elizabeth Andrew-Essien Dr. Eja Iwara Eja.

Institution awarding the Ph. D. Degree: University of Calabar, Calabar, Cross River State, Nigeria.

Date of defence: 20/07/ 2017

(C) 2018 Varna University of Management. All rights reserved

Citation: Odum, C. (2018) Evaluation of Potential Ecotourism Attractions for Sustainable Tourism Development in Anambra State, Nigeria. Doctoral Dissertation Summary. European Journal of Tourism Research 20, pp. 134-136

\section{Goal and objectives of the dissertation}

Goal

To evaluate potential ecotourism attractions for sustainable tourism development in Anambra State.

\section{Objectives}

1. To evaluate spatial distribution of selected ecotourism attractions in Anambra State.

2. To determine the socio-economic and socio-cultural significance of ecotourism attractions in communities selected.

3. To outline the ecotourism potential (attractiveness) of Anambra State.

4. To examine the challenges facing ecotourism development in Anambra State.

\section{Methodology}

Qualitative method was applied using indepth interviews and focus group discussions. In-depth interviews were carried out across the eight communities from March to September, 2015. Four interviews were carried out in each community with key informants namely: chief priests/priestess, cave guards, zonal forest officers, youth leaders, kings, town union presidents; while in the ministries, Director of tourism in Ministry of Information, Culture and Tourism and Director of Forestry in Ministry of Environment were interviewed within the stipulated months, precisely June. Focus Group Discussion (FGD) was carried out in all the communities and ministries. People selected for the FGD were selected based on the years of service in the ministries, while the community people were selected based on their age, experience and people living in close proximity with the 
study attractions. Quantitative method was also used for the study. A total of four hundred and eighty (480) questionnaires were distributed across the eight communities and four hundred and sixty-four (464) questionnaires were returned and used for the study. Forty (40) copies of questionnaires were given to both ministries each having twenty copies respectively. Fourteen copies were returned by Information, Culture and Tourism Ministry, while eleven (11) copies were returned by Ministry of Environment. A handheld Global Positioning System (GPS) was used to pick the coordinates of selected attractions. This was supported with secondary data generated for the study through journal articles, textbooks, government publications and other related literature in the library.

\section{Results}

The nearest neighbour analysis revealed that there is a regular distribution of ecotourism resources within the study locations with a nearest neighbour index result of 1.8. The Chi-square result also showed the use of ecotourism resources has a relationship between their use and their cultural and socio-economic values, although Amaokpala is an exception. There is a significant difference in the rating of tourism potential from demand and supply dimension. The tourism potential of all the ecotourism attractions studied fall between worst and bad with exception of Agulu Lake that recorded fair. This means that none of them is developed apart from Agulu Lake. This is not unconnected to the following challenges facing these ecotourism resources: lack of tourism facilities in the communities, nonmarketing of these caves by tourism stakeholders, logging to make money, demand for land to build houses, and lack of government interest. This accounted for their poor patronage by visitors and tourists. Two development options were accepted by all the communities namely: joint management of these attractions between government and community and public private partnership.

\section{Theoretical conclusion}

There is a lacuna in tourism development studies in Nigeria precisely Anambra State.
This study will fill in gap in academic world with knowledge about ecotourism resources/attractions in Anambra State, specifically, the quantified values/uses of ecotourism resources in different communities. It fills the gap in knowing how attractive ecotourism attractions in Anambra State are.

\section{Practical application of the dissertation}

The thesis can be used as a model to quantify uses or values of ecotourism resources. It can be applied in evaluating other natural resources of similar characteristics. The result of profile of visitors visiting these ecotourism attractions will be used in managing and developing similar ecotourism attractions. The thesis highlighted that ecotourism resources abound in Anambra State but none is developed. Joint management of these ecotourism resources between government and host communities is one of the ways to develop ecotourism resources in the State

\section{Content of the dissertation}

Abstract of Chapter 1

Chapter one looks at natural resources like caves, valleys, rivers, lakes, mountains, forests, etc. with emphasis on different sociocultural and socio-economic values for different communities. Utilizing these resources in a manner that guarantees sociocultural, environmental and economically sustainable is one attribute of ecotourism; this has made ecotourism to be preferred more than other forms of tourism. Anambra state is blessed with caves, lakes, forests, hills etc. Some of these natural resources are scattered in communities like: Ogbunike, Ufuma, Owerre-ezukala, Amaokpala, Agulu, Okpeze, Ndi-ukwenu, Awka etc. The major objective of this study is to evaluate ecotourism potential of Anambra State for sustainable tourism development. This is motivated by the undocumented nature of these natural attractions, unknown uses or significance of these attractions, limited knowledge of these attractions and many more.

\section{Abstract of Chapter 2}

Chapter two discusses the historical and contemporary views on ecotourism. Reviews 
on spatial distribution of tourism (cum ecotourism) resources and its implications; the socio-economic and socio-cultural values of ecotourism resources. A look at these studies on ecotourism resources in Anambra shows that majority of the studies used qualitative approach, none of them used quantitative method. The study adopted modernization and environmental communication theories. The former is anchored on development, conservation and positive impact of tourism use of these natural attractions and the latter highlights impact of human use of environment and associated implications.

\section{Abstract of Chapter 3}

Chapter three elaborates the methods used in the study. Survey design was used for this study. Qualitative and quantitative method was employed in eliciting data. Qualitative method was used in the study, mainly indepth interviews with key informants, and focused group discussion, while the quantitative aspect entails use of questionnaires administered in selected communities, ministries and visitors. A handheld Global Positioning System (GPS) was used to pick the coordinates of selected attractions. This was supported with secondary data from related studies. Data analysis was done using different statistical test (Manny Whitney U-test, Chi-square), tables, frequencies, charts etc; Arc GIS 10.1 (version) software was used in carrying out point pattern analysis, and weighted sum method was used to measure attractiveness of sampled ecotourism attractions.

\section{Abstract of Chapter 4}

Chapter four reveals the result of the study, which reads: nearest neighbour index showed a regular distribution pattern. Chi-square showed the values these communities attach to these resources is dependent on socioeconomic and cultural values it holds in these communities, while communities endowed with forests showed a result that means the use of forest is not dependent on the socioeconomic value in these communities. Manny Whitney U-test shows there is a significant difference in the rating of tourism potential in the study area from demand and supply dimension; this tally with results of weighted sum method.

\section{Abstract of Chapter 5}

Chapter five contains the summary of the study which states that, ecotourism attractions in Anambra state are not developed due to some challenges and its attractiveness is low. Meanwhile, these attractions hold unique significant value in the sampled communities. Therefore, any tourism development plan must be in tandem with synergies from these communities. Joint management and public private partnership hold a lot of promise for sustainable ecotourism development in Anambra State, Nigeria. 